\title{
Growth of celery [Apium graveolens L.] in the red-yellow podzolic soils as inoculated by earthworms Pontoscolex corethrurus
}

\author{
Pertumbuhan tanaman seledri (Apium graveolens L.) pada tanah podsolik merah- \\ kuning yang diinokulasi cacing tanah Pontoscolex corethrurus
}

\author{
Seprita Lidar ${ }^{1}$, Indra Purnama ${ }^{1,2 *}$ \\ ${ }^{1}$ Department of Agrotechnology, Faculty of Agriculture, Universitas Lancang Kuning, Pekanbaru, Indonesia \\ ${ }^{2}$ Research Center for Sustainable Indonesia, Pekanbaru, Indonesia
}

ARTICLE INFO

Article History

Received: December 17, 2020

Accepted: January 23, 2021

Published: $\quad$ February 21, 2021

Keywords:

celery,

RYP soil,

inoculation,

Pontoscolex corethrurus.

Cite this:

J. IIm. Pertan., 2021, 17 (2) 67-73

DOI:

https://doi.org/10.31849/jip.v17i2.5742

\section{ABSTRACT}

In this study, the inoculation effect of earthworms Pontoscolex corethrurus on celery growth (Apium graveolens L.) has been carried out in red-yellow podzolic (RYP) soils. The research studied in a pot experiment using a completely randomized design (CRD) with 6 (six) treatments and 3 (three) replications. One-pot consists of 4 (four) plants. The treatments carried out were as follows: $I_{0}$ (without inoculum of earthworm), $I_{1}$ (inoculum of 5 earthworms pot ${ }^{-1}$ ), $I_{2}$ (inoculum of 10 earthworms pot ${ }^{-1}$ ), $I_{3}$ (inoculum of 15 earthworms pot ${ }^{-1}$ ), $I_{4}$ (inoculum of 10 earthworms pot ${ }^{-1}$ ) and $I_{5}$ (inoculum of 25 earthworms pot $\left.^{-1}\right)$. Observation parameters were the number of tillers clumps $^{-1}$, fresh biomass clumps ${ }^{-1}\left(\mathrm{~g} \mathrm{clump}^{-1}\right)$, and root volume $(\mathrm{mL})$. The observations were statistically analyzed using variance (one-way ANOVA) and followed by the Duncan Multiple Range Test (DMRT) with a level of $5 \%$. Treatment $I_{5}$ gave the best results on celery crop in all parameters, i.e., 20.33 tillers per hill; fresh biomass per clump $113.93 \mathrm{~g}$; and a root volume of $10 \mathrm{~mL}$. The results showed that earthworms' inoculation into RYP soils significantly affected all parameters. There was also an increase in $\mathrm{pH}$ in each treatment that was inoculated with earthworms.

\section{INTRODUCTION}

In the culinary world, celery is a ubiquitous ingredient and used as a popular vegetable. Celery (Apium graveolens L.), a plant from the Apiaceae family, is known by the public as a spice or flavor enhancer for food. With a slightly spicy taste and distinctive aroma, celery is widely used in seasoning various food products (Sowbhagya, 2014). In Indonesia, celery is added for more flavors to traditional foods like bakso, soto, and soup in several cities.

Traditional medicine also utilized celery for ailments viz. fever, asthma, and high blood pressure (Kooti \& Daraei, 2017; Malhotra, 2006). The presence of compounds such as limonene, selinene, furanocoumarin, glycosides, flavonoids, vitamins $\mathrm{A}$, and $\mathrm{C}$ is why celery is also used as a medicinal plant (Malhotra, 2006). The previous study reports that celery can be used as a medicinal plant in fighting against SARS-CoV-2 (Rupasinghe, 2020; Shawky et al., 2020; Thakur et al., 2020). It makes celery will be a significant prospect for cultivated.

Fertile soil with a good nutrient content is one of the determining factors for celery crops. Besides, loose soil and pH 5.5 - 6.7 are the conditions for the success of celery cultivation (Malhotra, 2006; Sumpena \& Permana, 2020). The soil in Riau, Indonesia, is dominated by ultisol soils in the form of red-yellow podzolic (RYP) soils (Anggraini et al., 2019; Foller \& Silvina, 2017), which has unsuitable physical, chemical, and biological properties for celery cultivation.

RYP soil has a compacted structure, poor porosity, low $\mathrm{pH}$, low microorganisms, and poor nutrient content of $\mathrm{N}, \mathrm{P}$, and alkalis $(\mathrm{Ca}, \mathrm{Mg}, \mathrm{K}$, $\mathrm{Na}$ ). Also, RYP soil contains high $\mathrm{Al}$, which is toxic to plants and will fixate essential soil elements such as phosphorus (P) (Sri \& Karnilawati, 2018). To overcome the problem of RYP soil, many researchers treat RYP soil or 
other marginal soils so that it can be used in celery cultivation, such as adding alkaline fertilizer (Wu et al., 2019), organic fertilizers (Duaja, 2019), and even cultivated without the soil, just by using growing media (Adawiyah \& Afa, 2018). It is assumed that the inoculation of earthworms in RYP soil can also improve the soil properties to provide nutrients for a celery crop.

\section{$I_{1}: 5$ earthworms pot ${ }^{-1}$ \\ $\mathrm{I}_{2}: 10$ earthworms pot ${ }^{-1}$ \\ $\mathrm{I}_{3}$ : 15 earthworms pot ${ }^{-1}$ \\ $\mathrm{I}_{4}$ : 10 earthworms pot ${ }^{-1}$ $I_{5}: 25$ earthworms pot ${ }^{-1}$}

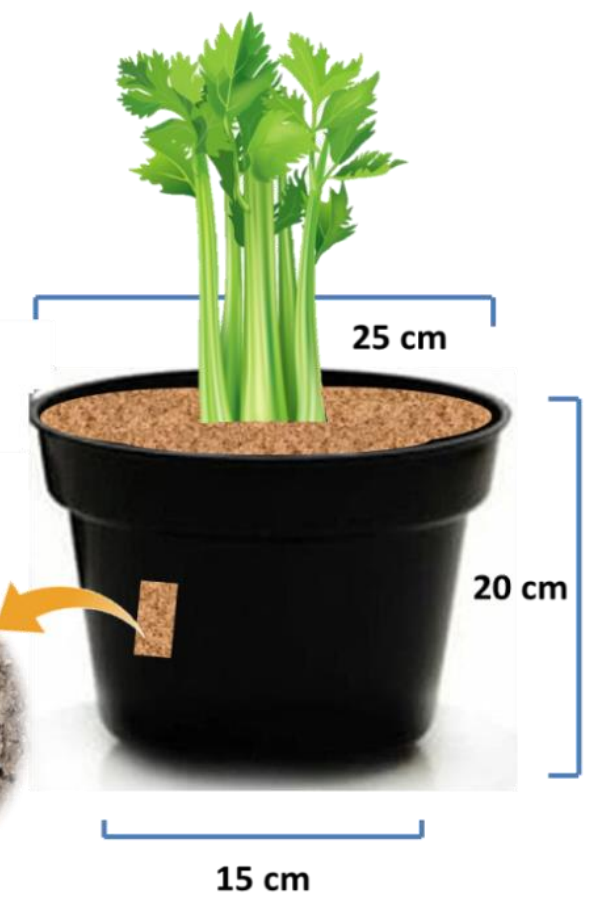

Figure 1. An illustration of the pot experiment in this study; $I_{0}$ as a control (without earthworm)

Earthworms are soil macrofauna that has a vital role in the soil ecosystem. Earthworms' existence is an indicator of soil fertility because, through their activities, earthworms can improve soil properties physically and chemically (Vidal et al., 2019; $\mathrm{Wu}$ et al., 2020). Physically, earthworms can improve soil texture and aeration, while chemically, through their digestive mechanism, remove dirt in the soil to increase the soil's availability (Sharma et al., 2017).

$P$. corethrurus, an earthworm species, is commonly found in agricultural lands, which has wide adaptability and tolerance of various environmental conditions ( $\mathrm{Lv}$ et al., 2016, 2020). Some of the plants reported to have shown significant results due to the inoculation of earthworms are pak choi (Lidar \& Surtinah, 2020), common bean (Barbosa et al., 2017), cabbage (Nurhidayati et al., 2016), and strawberries (Infante et al., 2018). So, based on the literature review so far, no study has been accomplished regarding the effect of earthworm inoculation in RYP soils for celery production. Therefore, the experiment was designed to find out the effect of earthworm inoculation in RYP soil on celery production.

\section{MATERIALS AND METHODS \\ Materials}

The variety of celery seed was Amigo. For earthworms, the species was $P$. corethrurush FR. Mull. Baglog (waste from oyster mushroom media) was utilized as a mixing material for RYP soils. The food source for earthworms used chicken manure during the preparation phase. Garlic extract was applied as natural pesticides. This study was performed with the pot experiment; gauze covered each hole at the bottom.

\section{Field site description}

The research was conducted at the experimental garden at the Faculty of Agriculture, Universitas Lancang Kuning Pekanbaru, Indonesia $(0.5779567,101.4250067)$ with an altitude of 16 masl. The type of soil was RYP soils, taken from the top $(0-20 \mathrm{~cm})$ with a $\mathrm{pH}$ measurement of 4.5 measured using Soil Tester DM-13.

Soil samples and baglog wastes were airdried and sieved through a $2 \mathrm{~mm}$ sieve as followed previous study (Purnama et al., 2015). The highest average temperature was $33{ }^{\circ} \mathrm{C}$, and 
the lowest average temperature was $23{ }^{\circ} \mathrm{C}$. Meanwhile, the rainfall was around $2000 \mathrm{~mm}$.

\section{Earthworm preparation}

Earthworms were obtained from the experimental garden and reared in a bucket with soil. The bucket was protected from direct sunlight and rain. Earthworms were nurtured for about three months by keeping the soil moist and feeding with the chicken manure (dried and finely ground). Earthworms $P$. corethrurus were selected uniformly, i.e., the adults were characterized by the presence of clitellum, length $(0.6-0.7 \mathrm{~cm})$, and weight $(0.58-0.68 \mathrm{~g})$.

\section{Experimental design}

The research was conducted by a pot experiment (as shown in Figure 1) using a completely randomized design (CRD) with 6 (six) treatments and 3 (three) replications. In total, there were 18 experimental pots. The experimental pots were prepared as follows: $\mathrm{I}_{\mathrm{o}}$ (without earthworm), $\mathrm{I}_{1}(5$ earthworms pot $\left.{ }^{-1}\right), I_{2}$ (10 earthworms pot $\left.{ }^{-1}\right), I_{3}(15$ earthworms pot $\left.{ }^{-1}\right), I_{4}\left(10\right.$ earthworms pot $\left.{ }^{-1}\right)$, and $I_{5}\left(25\right.$ earthworms pot $\left.{ }^{-1}\right)$.

Table 1. Effect of earthworm inoculation on the number tillers clump ${ }^{-1}$, fresh biomass ( clump $^{-1}$ ), and root volume $(\mathrm{mL})$ in a factorial pot experiment

\begin{tabular}{cccc}
\hline $\begin{array}{c}\text { Treatments } \\
(\text { earthworms pot }\end{array}$ & $\begin{array}{c}\text { Number } \\
(\text { tillers clump }\end{array}$ & $\begin{array}{c}\text { Fresh biomass } \\
\left(\text { g clump }^{-1}\right)\end{array}$ & $\begin{array}{c}\text { Root volume } \\
(\mathrm{ml})\end{array}$ \\
\hline $\mathrm{I}_{0}=0$ & $12.00 \mathrm{c}$ & $47.10 \mathrm{c}$ & $4.16 \mathrm{c}$ \\
$\mathrm{I}_{1}=5$ & $14.50 \mathrm{c}$ & $55.91 \mathrm{c}$ & $5.00 \mathrm{c}$ \\
$\mathrm{I}_{2}=10$ & $15.66 \mathrm{c}$ & $57.43 \mathrm{c}$ & $6.50 \mathrm{c}$ \\
$\mathrm{I}_{3}=15$ & $15.83 \mathrm{c}$ & $79.78 \mathrm{c}$ & $7.50 \mathrm{c}$ \\
$\mathrm{I}_{4}=20$ & $17.33 \mathrm{~b}$ & $88.26 \mathrm{~b}$ & $8.30 \mathrm{~b}$ \\
$\mathrm{I}_{5}=25$ & $20.33 \mathrm{a}$ & $113.93 \mathrm{a}$ & $10.00 \mathrm{a}$ \\
\hline
\end{tabular}

Numbers followed by the same letter were not significantly different based on the Duncan Test $p<0.05$

The growing media (4 $\left.\mathrm{kg} \operatorname{pot}^{-1}\right)$ was a mixture of RYP soil and baglog waste (5:1), incubated for a week to ensure a perfect mixing of the RYP soil and baglog before use in the pot experiment. The holes in the bottom of the pot had previously been covered by gauze. Then each pot was inoculated with earthworms according to the design.

Planting was completed two weeks after earthworm inoculation. The seeds were selected based on the seedling time (three weeks old after seedling), healthy, and the number of leaves (five pieces). Furthermore, watering was achieved until moist.

Every day the pots were watered with the same volume of water. Watering was stopped during the rains. Weed control was performed manually, while pests and diseases were controlled using natural pesticide prepared from garlic. NPK fertilizer $(16: 16: 16)$ was applied at a dose of $2 \mathrm{~g} \mathrm{plant}^{-1}$ when the plants were 15 days old. Celery harvesting was carried out after three months of rearing when they produced tillers.

\section{Parameters \& statistical analysis}

During the study, the parameters observed were the number of tillers clump-1, fresh biomass clump-1 (g clump-1), root volume (mL), and the earthworm population and soil $\mathrm{pH}$ of RYP at the end of the experiment.
The one-way ANOVA test was used for data analysis and followed by the DMCT test with a 5\% level using Microsft Excel 2010.

\section{RESULTS AND DISCUSSIONS}

The growing media with a mixture of 5 parts RYP soils and 1 part baglog waste was an effort to add nutrients in the RYP soil uniformly. Baglog is another term for oyster mushroom growing media. Baglog waste can no longer be used because it contains an exceptionally high amount of calcium (Ca); due to the addition of lime $\left(\mathrm{CaCO}_{3}\right)$ during the baglog-making process (Fitri et al., 2019). On the other hand, chicken manure fertilizer was mainly used for breeding earthworms in preparation (Ngosong et al., 2020; Vodounnou et al., 2016).

In this study, to control pests and diseases, natural pesticides were prepared from garlic. As is known, garlic containing active ingredients such as saponins, polyphenol flavonoids, and essential oils to control pests and diseases celery (Khairan et al., 2019). Malhotra (2006) revealed that insects pose comparatively less of a celery crop problem than do diseases. The primary disease of celery is early blight (Cercospora apii). Khairan et al. (2019) and Pande et al. (2017) have studied the fungicidal activity of garlic extract on Cercospora apii. The natural pesticide from garlic was prepared by following a previous study 
(Pande et al., 2017). Meanwhile, gauze was intended to cover the hole at the bottom of the plastic pot to prevent the entry of new earthworms from outside and also to prevent water stagnation in the pot.

Based on Table 1, it is clear that the inoculation of earthworms to RYP soil significantly affected all the parameters, including the number of tillers clump ${ }^{-1}$, fresh biomass clump ${ }^{-1}$, and root volume. The number of tillers clump ${ }^{-1}$ increased with the increase in numbers of inoculated earthworms. Treatment $I_{0}$, $I_{1}, I_{2}$, and treatment $I_{3}$ showed significant difference with treatment $\mathrm{I}_{4}$ and $\mathrm{I}_{5}$. The highest number of tillers clump ${ }^{-1}$ was found in treatment $I_{5}$ (20.33 tillers clump ${ }^{-1}$ ), while the lowest was found in treatment $\mathrm{I}_{\mathrm{O}}$, which was 12.00 tillers clump $^{-1}$. Fresh biomass clump ${ }^{-1}(\mathrm{~g})$ also showed a significant increase with the addition of earthworms. The increase in the number of earthworms inoculated into RYP soils also caused an increase in the root volume.

The observations on celery crops without earthworm inoculation showed the lowest performance in all experimental parameters. It is perhaps due to RYP soils' properties like compact structure, low $\mathrm{pH}$, and less nutrient available for celery crops. Also, low base cations and base saturation are responsible for making nutrientpoor soil, resulting in an inadequate celery yield. A study conducted by Wu et al. (2019) revealed celery crops in acidic soil, when added calcium cyanamide fertilizer (an alkaline), showed a highly significant increase in production. Meanwhile, when acidic soils only used urea, no significant effect in production was observed.

Celery crops that were inoculated with the earthworm had a significant effect on all the experimental parameters. With the inoculation of earthworms to RYP soil, the soil structure improves (Sharma et al., 2017). As a result, the water retention capacity and soil aeration also increase (Barbosa et al., 2017), which causes a better environment for organisms' lives in the soil. These organisms decompose organic matters in the soil smoothly and provide nutrients that are readily absorbed by celery crops.

Earthworms are one of the invertebrates in the soil which are decomposers and can increase soil fertility. The type of earthworm inoculated in this study is $P$. corethrurus, a type of worm beneficial to the soil and is widely found. Earthworms' role in increasing soil fertility through their activities, i.e., earthworm activity through movement in the soil, will increase soil porosity, so aeration and drainage conditions can be better. It will improve root performance in the soil, thereby increasing growth and production. Making burrows in the soil is not only to support the movement of earthworms and avoid environmental stress but also to store and digest food. After digestion, the remains of the ingested material are released back as solid waste (casting).

Worm casting, or better known as vermicast, contains beneficial microorganisms and nutrient elements that can be absorbed directly by plants so that the results could be seen in the experimental parameters. In line with studies conducted by Sinha (2011) and Vidal et al. (2019), casting can be an organic fertilizer that is proven to increase soil fertility, crop yields, soil microbial population, and reduce plant disease. Furthermore, Aladesida et al. (2014) stated that the soil with a high density of earthworm populations would be fertile because casting mixed with the soil are fertilizers: rich in organic nitrate, phosphate, and potassium, which make it plants easy to accept fertilizers given to the soil.

Overall, it can be seen that the highest results are found in treatment $\mathrm{I}_{5}$. It is thought that the more the number of earthworms that are inoculated, the soil becomes looser and fertile, so the growth and yield of celery crops will be more significant. Also, to the activity and nutrient content that is readily absorbed by plants, earthworm manure contains plant growth substances that can accelerate the absorption of nutrients for celery so that the measurement results of the experimental parameters are even more refined.

Tabel 2. Number of cocoons and juveniles produced by $P$. corethrurus at the end of the experiment $(\mathrm{n}=3)$

\begin{tabular}{ccc}
\hline Treatments & $\begin{array}{c}\text { Total } \\
\text { cocoons } \\
\left(\text { grain }^{-1}\right)\end{array}$ & $\begin{array}{c}\text { Total } \\
\text { juvenile } \\
\left.\text { (tail }^{-1}\right)\end{array}$ \\
\hline $\mathrm{I}_{0}$ & 0.0 & 0.0 \\
$\mathrm{I}_{1}$ & 2.7 & 3.7 \\
$\mathrm{I}_{2}$ & 3.0 & 4.0 \\
$\mathrm{I}_{3}$ & 3.3 & 4.7 \\
$\mathrm{I}_{4}$ & 3.7 & 5.7 \\
$\mathrm{I}_{5}$ & 4.0 & 6.0 \\
\hline
\end{tabular}

Based on observations of the earthworm population at the end of the experiment (see Table 2), it was founded cocoons and juveniles. It is assumed that earthworms are incredibly tolerant in RYP soil, even in acidic conditions with high exchangeable-Al content. Due to tolerance with various conditions, earthworms are also used in reducing waste or heavy metals in the environment (Bongoua-Devisme et al., 2019; Sanchez-Hernandez et al., 2019).

Table 2 shows that the number of cocoons and juveniles from earthworms will increase in 
line with the number of adult earthworms in the pot. However, the more earthworms inoculated into the soil, the increase in the number of juveniles and cocoons was insignificant. It was presumably due to the more inoculated earthworms had a limited space to move, so their reproduction was not as smooth as the number of earthworms was relatively less (Barbosa et al., 2017).

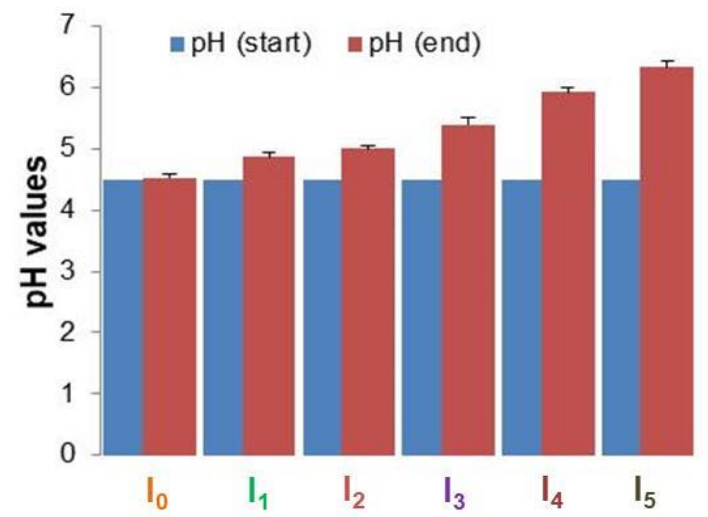

Figure 2. Soil $\mathrm{pH}$ influenced by earthworm in different treatments $\left(\mathrm{I}_{0}\right.$ : control soil/without earthworm; $\mathrm{I}_{1}$ : 5 earthworms inoculation pot $^{-1} ; \mathrm{I}_{2}$ : 10 earthworms inoculation pot $^{-1} ; \mathrm{I}_{3}$ : 15 earthworms inoculation pot $^{-1} ; \mathrm{I}_{4}: 10$ earthworms inoculation pot${ }^{1}$; and $\mathrm{I}_{5}$ : 25 earthworms inoculation pot $^{-1}$ ).

The proliferation of earthworms in treated RYP soils also increased RYP soils' pH, as seen in Figure 2. The same phenomenon also occurred in previous studies (Wu et al., 2020), the strong ability of the earthworm in reducing soil acidification due to the presence of calciferous glands (Ayten Karaca, 2011; García-Montero et al., 2013) and skin mucous secretions, including urine, $\mathrm{NH}^{4+}$, and exchangeable $\mathrm{Ca}^{2+}, \mathrm{Mg}^{2+}, \mathrm{K}^{+}$ (Sizmur \& Hodson, 2009). The ability of earthworms to increase $\mathrm{pH}$ is thought to have modified the exchangeable $\mathrm{Al}$ fraction in the RYP soil to reduce the bio-toxicity of exchangeable Al. It is in line with a study conducted by Wu et al. (2020), increased $\mathrm{pH}$ of acidic soil due to inoculation of earthworms impacts reducing exchangeable $\mathrm{Al}$ by up to $61.7 \%$.

\section{CONCLUSIONS}

Inoculation of earthworm $P$. corethrurus significantly increased the total number of tillers, fresh biomass, and the celery crop's root volume in RYP soils compared with the control that absence of earthworms. Treatment $\mathrm{I}_{5}$ gave the best results on the celery crop. Treatment $\mathrm{I}_{5}$ gave the best results on celery crop in all parameters, i.e., 20.33 tillers per hill; fresh biomass per clump $113.93 \mathrm{~g}$; and a root volume of $10 \mathrm{~mL}$. This research shows that RYP can also be used as a growing media when earthworms are inoculated apart from fertilizers. This study also reveals that earthworms can improve the properties and structure of the soil. Further research is needed to analyze the soil's physical and chemical properties at the beginning and the end of the experiment.

\section{DECLARATION}

The authors have no conflicts of interest to declare that are relevant to the content of this article.

\section{REFERENCES}

Adawiyah, R., \& Afa, M. (2018). Pertumbuhan Tanaman Seledri (Apium graveolens L.) Pada Berbagai Media Tanam Tanpa Tanah Dengan Aplikasi Pupuk Organik Cair ( Poc ). Biowallacea, 5(1), 750-760.

Aladesida, A., Dedeke, G., Ademolu, K., \& Museliu, F. (2014). Nutrient Analysis of Three Earthworm Cast-Types Collected From Ikenne, Ogun State, Nigeria. Journal of Natural Science, Engineering and Technology, March 2015, 36-43.

Anggraini, R. S., Zona, R. F., Candra, E., \& Sutrisna, N. (2019). Model of organic fertilizer utilization made from local agricultural waste as soil fertilizer in Riau Province. Innovation of Environmental-Friendly Agricultural Technology Supporting Sustainable Food Self-Sufficiency, 2OO1, 503-510. https://doi.org/10.5281/zenodo.3345583

Ayten Karaca. (2011). Biology of Earthworms. Chapman \& Hall.

Barbosa, J. Z., Demetrio, W. C., Silva, C. M., \& Dionísio, J. A. (2017). Earthworms (Amynthas spp.) increase common bean growth, microbial biomass, and soil respiration. Semina:Ciencias Agrarias, 38(5), 2887-2898. https://doi.org/10.5433/16790359.2017v38n5p2887

Bongoua-Devisme, A. J., Akotto, O. F., Guety, T., Kouakou, S. A. A. E., Ndoye, F., \& Diouf, D. (2019). Enhancement of phytoremediation efficiency of Acacia mangium using earthworms in metal-contaminated soil in Bonoua, Ivory Coast. African Journal of Biotechnology, 18(27), 622-631. https://doi.org/10.5897/ajb2019.16852

Duaja, M. D. (2019). Response of celery plant (Apium graviolens L.) to the reduction of inorganic fertilizer with decanter cake usage. Agric, 31(1), 31-40. https://doi.org/10.24246/agric.2019.v31.i1.p 31-40

Fitri, K., Yaya, S., \& Rina, N. (2019). The effect of planting media composition on the growth and yield of oyster mushrooms (Pleurotus ostreatus (Jack) P. Kumm. Media Pertanian, 4(2), 59-68. 
Foller, R., \& Silvina, F. (2017). The Effect of Growing Media Mix Peat With Red-Yellow Podzolik on the Growth of Seedlings of Oil Palm(Elaeis guineensis jacq) in the Main Nursery. JOM FAPERTA, 4(1).

García-Montero, L. G., Valverde-Asenjo, I., GrandeOrtíz, M. A., Menta, C., \& Hernando, I. (2013). Impact of earthworm casts on soil pH and calcium carbonate in black truffle burns. Agroforestry Systems, 87(4), 815-826. https://doi.org/10.1007/s10457-013-9598-9

Infante, M. G., Guerrero, M. A., Vega, C. B., Demetrio, W. C., \& Dionísio, J. A. (2018). Earthworms and Fusarium oxysporum: Effect on strawberry plant growth and production. Semina:Ciencias Agrarias, 39(4), 1437-1446. https://doi.org/10.5433/16790359.2018v39n4p1437

Khairan, K., Aulina, A., Bahi, M., Nova Eriana, C., \& Sriwati, R. (2019). Fungicidal activity of garlic (Allium sativum) bulbs extracts against plants phatogenic fungi. Jurnal Hama Dan Penyakit Tumbuhan Tropika, 19(1), 23. https://doi.org/10.2396o/j.hptt.11923-32

Kooti, W., \& Daraei, N. (2017). A Review of the Antioxidant Activity of Celery (Apium graveolens L). Journal of Evidence-Based Complementary and Alternative Medicine, 22(4), 1029-1034. https://doi.org/10.1177/2156587217717415

Lidar, S., \& Surtinah, S. (2020). Plant Response Due to Inoculation of Fr.Mull Earthworm (Pontoscolex Corethrurus): Pakchoy (Brassica Rapa L) Context. IOP Conference Series: Earth and Environmental Science, 469(1). https://doi.org/10.1088/17551315/469/1/012019

Lv, M., Fu, S., Shao, Y., Lin, Y., Wu, J., \& Zhang, W. (2020). Earthworm Pontoscolex corethrurus stimulated soil $\mathrm{CO} 2$ emission by enhancing substrate availability rather than changing microbiota community structure. Science of the Total Environment, 717, 137227. https://doi.org/10.1016/j.scitotenv.2020.137 227

Lv, M., Shao, Y., Lin, Y., Liang, C., Dai, J., Liu, Y., Fan, P., Zhang, W., \& Fu, S. (2016). Plants modify the effects of earthworms on the soil microbial community and its activity in a subtropical ecosystem. Soil Biology and Biochemistry, 103, 446-451. https://doi.org/10.1016/j.soilbio.2016.09.02 o

Malhotra, S. K. (2006). Celery. In Handbook of herbs and spices (pp. 317-336). http://www.sciencedirect.com/science/articl e/pii/B978184569017550018X

Ngosong, C., Nfor, I., Tanyi, C., Olougou, M., Sone, K., Agbor, D., Ndakwe, A., Nanganoa, L., \& Tening, A. (2020). Effect of poultry manure and inorganic fertilizer on earthworm population and soil fertility: implication on root nodulation and yield of climbing bean (Phaseolus vulgaris). Fundamental and Applied Agriculture, 5(o), 1. https://doi.org/10.5455/faa.76612

Nurhidayati, N., Ali, U., \& Murwani, I. (2016). Yield and Quality of Cabbage (Brassica oleracea L. var. Capitata) Under Organic Growing Media Using Vermicompost and Earthworm Pontoscolex corethrurus Inoculation. Agriculture and Agricultural Science Procedia, 11, 5-13. https://doi.org/10.1016/j.aaspro.2016.12.00 2

Pande, S. K., Chaubey, A. N., Singh, V., \& Pal, K. (2017). Eco-friendly management of cercospora leaf spot (cercospora rauvolfia) of sarpgandha. Plant Archives, 17(1), 546-548.

Purnama, I., Malhat, F., Jaikaew, P., \& Ahmed, T. (2015). Toxicological \& Environmental Chemistry Degradation profile of azoxystrobin in Andisol soil: laboratory incubation. May, 37-41. https://doi.org/10.1080/02772248.2015.101 5297

Rupasinghe, H. P. V. (2020). Special Issue "Flavonoids and Their Disease Prevention and Treatment Potential": Recent Advances and Future Perspectives. Molecules, 25(4746), $1-7$.

Sanchez-Hernandez, J. C., Ro, K. S., \& Díaz, F. J. (2019). Biochar and earthworms working in tandem: Research opportunities for soil bioremediation. Science of the Total Environment, 688(June), 574-583. https://doi.org/10.1016/j.scitotenv.2019.06. 212

Sharma, D. K., Tomar, S., \& Chakraborty, D. (2017). Role of earthworm in improving soil structure and functioning. Current Science, 113(6), 1064-1071. https://doi.org/10.18520/cs/v113/io6/10641071

Shawky, E., Nada, A. A., \& Ibrahim, R. S. (2020). Potential role of medicinal plants and their constituents in the mitigation of SARS-CoV2: Identifying related therapeutic targets using network pharmacology and molecular docking analyses. RSC Advances, 1O(47), 27961-27983.

https://doi.org/10.1039/dora05126h

Sinha, R. (2011). Organic Farming by Vermiculture: Producing Safe, Nutritive and Protective Foods by Earthworms (Charles Darwin's Friends of Farmers). American Journal of Experimental Agriculture, 1(4), 363-399. https://doi.org/10.9734/ajea/2011/519

Sizmur, T., \& Hodson, M. E. (2009). Do earthworms impact metal mobility and availability in soil? - A review. Environmental Pollution, 157(7), 1981-1989. https://doi.org/10.1016/j.envpol.2009.02.02 9 
Sowbhagya, H. B. (2014). Chemistry, Technology, and Nutraceutical Functions of Celery (Apium graveolens L.): An Overview. Critical Reviews in Food Science and Nutrition, 54(3), 389-398. https://doi.org/10.1080/10408398.2011.586 740

Sri, H., \& Karnilawati. (2018). Karakterisasi dan klasifikasi tanah Ultisol di Kecamatan Indrajaya Kabupaten Pidie. Jurnal Ilmiah Pertanian, 14(2), 52-59.

Sumpena, U., \& Permana, A. (2020). Budidaya seledri menggunakan pot/polybag. Balai Penelitian Tanaman Sayuran. http://balitsa.litbang.pertanian.go.id/ind/im ages/Isi poster/MP-29 Budidaya seledriKRPL.pdf

Thakur, S., Mayank, Sarkar, B., Ansari, A.J, Khandelwal, A. Arya, A., Poduri, \& R., Joshi, G. (2020). Exploring the magic bullets to identify Achilles' heel in SARS-CoV-2: Delving deeper into the sea of possible therapeutic options in Covid-19 disease: An Update. Food and Chemical Toxicology.

Vidal, A., Watteau, F., Remusat, L., Mueller, C. W., Nguyen Tu, T. T., Buegger, F., Derenne, S., \& Quenea, K. (2019). Earthworm cast formation and development: A shift from plant litter to mineral associated organic matter. Frontiers in Environmental Science, 7 (APR), $1-15$. https://doi.org/10.3389/fenvs.2019.00055
Vodounnou, D. S. J. V., Kpogue, D. N. S., Tossavi, C. E., Mennsah, G. A., \& Fiogbe, E. D. (2016). Effect of animal waste and vegetable compost on production and growth of earthworm (Eisenia fetida) during vermiculture. International Journal of Recycling of Organic Waste in Agriculture, 5(1), 87-92. https://doi.org/10.1007/s40093-016-0119-5

Wu, J., Zhang, C., Xiao, L., Motelica-Heino, M., Ren, Z., Deng, T., \& Dai, J. (2020). Impacts of earthworm species on soil acidification, $\mathrm{Al}$ fractions, and base cation release in a subtropical soil from China. Environmental Science and Pollution Research, 27(27), 33446-33457. https://doi.org/10.1007/s11356-019-05055-8

Wu, Y., Wu, J., Ma, Y., Lian, Y., Sun, H., Xie, D., Li, Y., Brookes, P. C., \& Yao, H. (2019). Dynamic changes in soil chemical properties and microbial community structure in response to different nitrogen fertilizers in an acidified celery soil. Soil Ecology Letters, 1(3-4), 105113. https://doi.org/10.1007/s42832-019o012-z 